\title{
Do Economic Policymakers Practice what they Preach? The Case of Pension Decisions
}

\author{
Momi Dahan \\ Tehila Kogut \\ Moshe Shalem
}

CESIFO WORKING PAPER NO. 2783

CATEGORY 1: PUBLIC FINANCE

SEPTEMBER 2009

Presented At CESifo Venice Summer Institute, July 2009

An electronic version of the paper may be downloaded

- from the SSRN website:

www.SSRN.com

- from the RePEc website:

- from the CESifo website:

www.RePEc.org

www.CESifo-group.org/wp 


\title{
Do Economic Policymakers Practice what they Preach? The Case of Pension Decisions
}

\begin{abstract}
This paper examines whether policymakers, economists at the Israeli Finance Ministry, act in their personal pension decisions in accordance with the rational behaviour assumptions underlying the pension policies they advance. We find that while economists' decisions regarding three other important decisions such as buying an apartment, a car and a large appliance, are largely in line with rational models, pension decisions deviate significantly from these models. A large share of these policymakers hardly search for relevant information regarding their chosen pension fund, do not know the most necessary information and consider only one option before choosing the preferred pension fund. A significant difference was found between specialized policymakers (economists in the Pension Division) and general policymakers (economists in all other Divisions) showing that specialized policymakers are significantly less biased.
\end{abstract}

JEL Code: A10, A11, G18, G23, H00.

Keywords: policymaking, pension decisions, expert, rational choice.

\author{
Momi Dahan \\ The Hebrew University of Jerusalem \\ Faculty of Social Sciences \\ Mt. Scopus \\ Israel - Jerusalem 91905 \\ momidahan@mscc.huji.ac.il \\ Tehila Kogut \\ kogut@bgu.ac.il \\ Moshe Shalem \\ moshesh@mof.gov.il
}

August 2009

We are very grateful to Eran Feitelson and Ilana Ritov for their valuable comments and discussions. We also benefited from the comments of seminar participants at Venice Summer Institute, the School of Public Policy (Hebrew University) and the Israel Democracy Institute. We thank Yulia Unger and Ori Sharf for excellent research assistance. 


\section{Introduction}

In recent years, individual choice became a cornerstone in much of the economic reforms undertaken in Israel, like many other developed countries. The pension system, in particular, went through a dramatic change in which employees were given more freedom to choose between various schemes (defined contribution, defined benefits and hybrid of defined contribution and benefits) and between a variety of pension funds and portfolio selections. ${ }^{1}$ Even the pay-as-you-go pension system for public sector employees has been replaced by DC or DB plans run by private funds.

The economic policy experts at the Ministry of Finance play a central role in initiating, designing and implementing several pension reforms. The professional staff from all divisions at the Finance Ministry was even more important with regard to the pension reform, given the degree of professionalism needed in crafting these reforms.

In line with rational models, the underlying assumption of those who led the pension reform is that employees collect and process the relevant information, go through an adequate number of pension schemes and alternative pension funds and choose a pension scheme/fund that fits their preference best. To arrive at the optimal saving for retirement, lay people are required to solve a very complex problem that includes the estimation of the expected lifetime earnings, future interest rates, anticipated family status and longevity. The implicit assumptions that lay people have the cognitive ability necessary to solve that optimization problem as well as the willpower to carry out the resulting plan have been questioned by behavioral economists. ${ }^{2}$

The goal of this paper is to study whether economic policymakers who have proposed and implemented major policy reforms in the pension system do act rationally in their personal saving decisions as would be expected by their own key assumption of rationality.

\footnotetext{
${ }^{1}$ See Mitchell and Utkus (2004) for the global trend towards spurring individual choice in pension decision.

${ }^{2}$ Saving decisions by ordinary people are influenced by framing (Madrian and Shea, 2001; Choi et al, 2002, 2004), characterized by procrastination or inertia (Madrian and Shea, 2001), tendency to use spouses and friends as advisors (Benartzi and Thaler, 1999). See Benartzi and Thaler (2007) for a survey of empirical works on the deviations of lay people from rational models in the decision to save for retirement.
} 
A long-standing debate in the judgment and decision making literature exists between two contrasting views on whether judgments and decisions made by experts are different from that of lay people. ${ }^{3}$ The skeptical view can be summarized by Mark Twain's definition of expert, "an ordinary fellow from another town". In a series of works Tversky and Kahneman (1971, 1973, 1974) argue that individuals use judgmental heuristics that may lead to severe and systematic errors. With respect to experts, Tversky and Kahneman (1974) have pointed out that reliance on heuristics and the prevalence of biases is not limited to lay people. Kahneman (1991) is even more explicit: "there is much evidence that experts are not immune to cognitive illusions that affect other people".

Indeed, a number of studies establish that biases exist among trained professionals, such as real estate agents (Northcraft and Neale, 1987), school psychologists (Davidow and Levinson, 1993), managers (Olsen, 1997; Bazerman, 1998; Hodgkinson et al, 1999) and physicians (Hall, 2002).

In contrast, others (e.g. Alba and Hutchinson, 1987) argue that experts, who are more experienced, are less influenced by external factors and therefore are less susceptible to context and manipulations, such as differences in task (Coupey, Irwin, and Payne, 1998), the salience of different attributes (Wright and Rip, 1980) or priming effects (Bettman, and Sujan, 1987; Mandel and Johnson 2002).

Thus far, judgment literature has extensively covered the use of heuristics and biases by experts and lay people, but almost overlooked a third important group: policymakers, due to the difficulties in collecting data from this special group (as the focus of this paper is on expert decision makers and not politicians). The existence of cognitive biases among policymakers may even have a more significant effect. Decisions made by policymakers affect the life of many people, unlike experts, who influence only those seeking their advice.

\footnotetext{
${ }^{3}$ A closely related literature concerns with the question of whether experts outperform novices. See Camerer and Johnson who portray a dismal picture based on the performance of experts in most clinical and medical domains and Shanteau (1992) for a review of a study which provides more favorable view of experts; in certain domains experts tend perform well.
} 
We investigate biases among a group of policymakers (expert economists) at the central office in the Israeli Finance Ministry, who are more likely to be influenced by rational choice theories in their professional training. The paper focuses on possible biases or deviations from rationality in saving behavior of policymakers by comparing pension decisions with three other major decisions (purchasing an apartment, a car and a large appliance). Following Shanteau (1992) and Das and Teng (1999) who suggest that basic types of biases exist selectively and at different levels among experts, we also compare between saving behavior of specialized and general policymakers.

Policymakers are divided into two sub-groups where the first sub-group consists of economists from the Capital Market, Insurance and Pension Division who are frequently engaged in regulating the pension market and designing pension reforms (specialized policymakers) and the second sub-group contains economists from all other divisions who are less involved in pension decisions on a daily basis (general policymakers) but took part in pension reforms. This comparison of judgment processes between the two sub-groups would allow us to study the effect of degree of expertise on cognitive biases.

By examining whether economic policymakers follow the assumptions of rational choice theories, our research could be used to evaluate the efficacy of a common suggestion: to provide financial education in order to improve pension decisions made by the general public. In that respect, the presented research may have important implications on economic policy.

In addition, this paper might raise the awareness of policymakers to cognitive biases in crafting economic policy. This objective should not be underestimated given that the global trend in economic policy towards more freedom of choice has been occurring despite the accumulating evidence of biases among lay people and even experts in certain domains.

\section{Theoretical background: deviations from rational models}

There are numerous ways to characterize a deviation from rational choice models especially with regard to pension decisions, given the complexity of that choice. According to rational decision-making models, a choice decision is a cognitive process 
in which one should consider all possible solutions (options) and search for the relevant information regarding each option. One should weigh up the alternatives, calculate their consequences and likelihood, and come up with the best potential result (for an overview see Bazerman, 1998, chapter 1, Baron, 2000, chapter 3). These models require a great deal of time and information processing, which are not always worthwhile to invest. In addition, in many choice situations it is not possible to consider every option, and to know its future consequences.

The 'bounded rationality' approach (Simon 1956) suggests that decision makers may consider fewer options than are actually available, knowing that they choose an option that is not the best overall, but is best within the given circumstance. According to bounded rationality theory, the mind has evolved shortcut strategies that produce reasonable solutions. The bounded rationality viewpoint still expects the decision makers to look for appropriate information and examine options before making a choice, but within limitations, including the cost of acquiring information. Therefore, when the decision maker is an expert in the decision's domain, s/he should look for more information than a lay decision maker, given the lower costs of searching due to better accessibility to relevant information and the ability to understand and integrate the information (Phelps and Shanteau, 1978).

\section{Surveys design and empirical methods}

\subsection{Overview of the surveys}

Two surveys were conducted in the current paper. A pilot study was first circulated that intended to learn about the recommended behavior regarding a pension decision as perceived by economic policymakers and to identify the main dimensions which they perceive as important for the decision. Following the pilot survey, the main survey was designed to study the actual behavior of policymakers from the same ministry.

In the pilot survey, the participants were not asked about their own decisions. Instead they were asked about the appropriate approach one should have when making the decision. Therefore they were free to think objectively about these issues. Participants' responses in the pilot study serve as a reference point for economists' real behavior as will be reported by the participants in the main study. Since participants in both studies 
are economic policymakers working in the same place, this comparison will allow us to examine whether participants' actual decision deviate from the recommended behavior.

\subsection{Pilot study}

\subsubsection{Method}

Twenty two economists working in the Israeli Ministry of Finance office participated in this pilot study. This is an acceptable number given that the overall population of economic policymakers is small. They responded to a short survey regarding the importance of different decisions in life. Participants were first asked to rate the importance of four different decisions each on a seven point scale (ranging from 1- not important at all, to 7- very important). The decisions include: buying an apartment, buying a new car, choosing a pension plan and purchasing a large appliance. Next they were asked to scale these four decisions, from the least important to the most important one (1-4). They were also asked to indicate how many alternatives one should ideally examine before making each of the above the decisions. Finally, an open question was included about the type of information one should have at the time of the decision.

\subsubsection{Results}

Results of a repeated measures analysis reveals a significant difference between ratings of the importance of the four different decisions $(F(1,21)=78.44, p<.001)$, such that participants rated the decision concerning a pension plan $(\mathrm{M}=5.41)$ and purchasing an apartment ( $\mathrm{M=6.36)}$ as more important than the other two decisions (buying a car, $\mathrm{M}=$ 3.64, and a large appliance, $M=2.55$ ); no significant difference was found between the importance of the two former decisions nor between the two latter ones (Table 1). ${ }^{4}$

Turning next to participants' opinions regarding the number of options one should ideally examine before making the decision; again there was a significant difference between the four types of decisions $(\mathrm{F}(1,21)=24.33, \mathrm{p}<.001)$, participants thought that one should examine significantly more options before buying an apartment, $(\mathrm{M}=6.00)$, than before choosing a pension plan $(\mathrm{M}=5.00)$.

\footnotetext{
${ }^{4}$ Similarly, scale ratings show a significant difference between ratings of the relative importance of the four decisions $(\mathrm{F}(1,21)=105, \mathrm{p}<.001)$, with pension plan $(\mathrm{M}=3.27)$ and apartment purchasing $(\mathrm{M}=3.59)$ being rated as more important than the other two decisions (buying a car, $\mathrm{M}=2.14$, and a large appliance, $\mathrm{M}=1.00$ ).
} 
Both the number of options one should examine before deciding on buying a new car ( $M=4.18)$, and a large appliance $(M=3.36)$ were significantly lower than the number of options required before choosing a pension plan. Specifically for the pension plans, the number of options ranged between 3- 7. In particular, none of the participants thought that it is reasonable to examine one option or even less than three options.

Most of the participants indicate that people should have information on long run rate of return (more than 80\%) and managerial fees (more than 50\%). Participants also mentioned other types of information such as risk (six participants), quality of service (four participants) and variety of products (four participants).

As explained earlier, one of the main aims of the pilot study was to allow a comparison between economists' recommendation and actual behavior in their real private pension decisions. Rational decision makers are expected to invest more time and resources in the decision, as the decision is perceived to be more important to them. For example, participants rated pension decision as significantly more important than the decision of choosing a new car. Therefore, investing more time and searching for more information before buying a car, as compared with the same type of resources invested in choosing a pension plan would be considered a departure from rationality.

\subsection{The main study}

\subsubsection{Participants}

The main questionnaire was answered in January 2008 by a significant share of economic policymakers in the Israeli Finance Ministry (136 economic policymakers from all divisions at the central office). The participants in our study represent almost 40 percent of the professional staff at the central office of the Israeli Finance Ministry. ${ }^{5}$ The questionnaire has been distributed to all policymakers at a particular point in time. Thus, those who were not in their office either because they were in meetings outside their office at that moment or on vacation did not participate. ${ }^{6}$

\footnotetext{
${ }^{5}$ The total number of employees at the central office is around 800 and of which about half is occupied by the administrative staff (2008 Budget, Ministry of Finance).

${ }^{6}$ The rejection rate was quite small, only 5 economists refused to cooperate.
} 
Participants' ages ranged from 23 to 48 years old, $(M=31.5)$; years of service at the finance ministry ranged from 2 to 20 years, $(M=4.3)^{7}$

The economic policymakers are well trained economists. All of them have a bachelor's or master's degree in economics, accounting or business administration. They are recruited after a relatively long screening process and are perceived as the elite of the public service in Israel.

All public employees hired after April 2002 had to select a private pension (DB) or private provident fund (DC) to invest their pension saving which replaced the previous public pay-as-you-go program. ${ }^{8}$ For obvious reasons, new economists who had just joined the finance ministry and are not entitled yet to pension rights and economists who were in a public pay-as-you-go pension program were not included as well in our sample. ${ }^{9}$ The enrollment in pension saving is mandatory.

An employee that was hired after April 2002 (which includes 60\% of the participants in our survey) had to choose from a list of 20 pension/provident funds which include also a blank place for those who opt for a pension/provident fund outside that list. ${ }^{10}$ This is a typical list that is provided also by private employers. For example, the Israeli branch of Intel provides a similar list to its newly hired workers. Employees are granted up to two weeks to fill out a form with their selected pension/provident fund otherwise they do not receive their salary slip. It is important to emphasize that employees are not offered a default retirement plan by the employer (the government) or by their union.

Since the stabilization program in 1985, the professional staff in the Israeli finance ministry plays a key role in initiating, designing and implementing economic policy. The general belief in Israel is that this group of economic policy experts has no less influence than political policymakers. This has a visible appearance even in popular

\footnotetext{
${ }^{7}$ We examine whether participants' responses are influenced by years of service, to account for the retrospective nature of the questionnaire. No significant correlations were found between years of service and the main variables. In particular, no significant differences were found between a group of 27 economists who responded to the questionnaire within their first year of service and the rest of the participants.

${ }^{8}$ The public pay-as-you-go pension program was not open to government workers at very top (senior staff) and bottom (temporary workers) even before April 2002. They had to choose between DC and DB.

${ }^{9}$ Those who were recruited before April 2002, and were in a public in pay-as-you-go pension program, consist of approximately $30 \%$ of the professional staff (estimates provided by the Wage Commissioner Ministry of Finance)

${ }^{10}$ Recently, that form has been changed and no pension fund appears on the new form.
} 
press. For example, the head of the Capital Market, Insurance and Pension Division was third in the list of 100 most influential people in Israel published by a leading economic newspaper in Israel (The Marker, 2004). Moreover, top officials from the finance ministry are frequently invited to give interviews and they do not hesitate to make policy statements that should be restricted to politicians.

In a more systematic work, Ben-Bassat (2008) has shown that the likelihood of an economic reform to be adopted is very slim without the consent of the professional staff of the finance ministry. A recent study on the balance of powers in the budgeting process found that the degree of centralization in Israel is among the highest in the developed countries (Ben-Bassat and Dahan, 2006). They found that the finance ministry is very powerful at all three stages of the budgeting process: preparation, legislation and implementation of the budget.

The professional staff is divided into two groups. The first group, which is defined here as specialized policymakers, consists of 38 economists from Capital Market, Insurance and Pension Division. Those experts have been involved deeply in crafting the major pension reforms that took place in recent years. This group of experts also regulates capital market in general, and pension funds in particular.

The second group which is defined here as general policymakers, includes 98 economists from all other divisions at the central office of the Israeli Finance Ministry. ${ }^{11}$ Obviously, the specialized policymakers have played a prominent role in designing pension reforms; but other economists (general policymakers) and especially those from Budgeting Division were very influential as well.

\subsubsection{The questionnaire}

The main questionnaire contains between 10 and 18 questions (in closed form) for each of the four decision contexts. The first section deals with buying an apartment, the second concerned a car purchasing, the third section covers the decision of choosing a pension fund and the last one is about purchasing a large appliance. Participants were instructed to complete the questionnaire without referring to previously completed pages and to skip sections of the questionnaire that are not relevant to them. For

\footnotetext{
11 Two of these general policy makers completed only partially the pension section of the questionnaire.
} 
example, those who had not bought an apartment in the last 10 years (or a car/large appliance in the last five years) were asked to skip that section.

The inclusion of four contexts of personal decision making was intended to hide the purpose of the study and also to allow for a comparison (as explained earlier). The questionnaire included three questions on the extent of search for relevant information on three key parameters rated on a seven point scale. In the pension section the three key parameters were: managerial fees, long-run financial rate of return, and demographic rate of return. ${ }^{12}$ The Israeli Finance Ministry provides a comparative data on these parameters on its web site (pension net) to assist workers to choose between pension funds, and that signifies the importance of those three variables in the eyes of economic policymakers.

The questionnaire proceeded with a question for the number of alternative options considered, the time it took to decide, extent of advice from co-workers/close relatives/experts, and two questions on the degree of satisfaction from the decision: First, participants were asked to rate the extent to which they feel that they have made the right decision when choosing a pension plan (or purchasing an apartment, a car or a large appliance). Second, participants were asked to rate, on a seven point scale, their agreement to the sentence: "I would be happier if I had more of the relevant information at the time of the decision"

The questions in all four sections were formulated in a similar fashion to allow for a meaningful comparison between various decisions. For example, for the apartment purchasing decision, participants were asked about the extent to which they searched for information about the prices, the neighborhood quality and mortgage interest rates.

\subsection{Empirical Methods}

In order to examine participants' biases in their private pension decisions in the current research, we focus on the most basic and minimal features of rationality (or even bounded rationality). Given the large number of alternatives (pension plans) and the complexity of the information, we do not expect decision makers to examine every

12 The total rate of return in a DB plan in Israel is the sum of financial rate of return and demographic rate of return which is affected by risk management (related to life expectancy and disability). 
option. On the other hand, examining only one option does not give a comparable view and therefore would be considered as a deviation from rationality.

Decision makers are also not expected to search for all the available information regarding the options that are being considered. Decision makers are expected to have the most relevant information (which in the case of pension decision includes the information regarding the management fees, financial rate of return and demographic rate of return and minimally to know that information regarding the chosen option. Note, that most economists in the pilot study suggest that individuals should have information on these key parameters before choosing a pension fund.

The degree of subjective importance of the decision, as compared to other important decisions in life, should influence the amount of resources and effort invested in the decision. The more important the decision maker perceives the decision task, the more s/he is expected to invest in the decision process by examining more options, searching for more information regarding the considered options and spending more time on the decision process.

In sum, three criteria are used separately to determine a deviation from rationality: if investment in the decision, which is represented by three features (the extent of the search for information, time spent and number of options considered), is not in accordance with its perceived importance, if participants examine one option or if participants lack the most relevant knowledge regarding the chosen option. OLS regressions are employed to test the first criterion and a repeated (or simple) measures analysis for the other two criteria.

To study whether the self-reported investment in the decision by policymakers in the main study is consistent with the suggested behavior recommended by the policymakers in the pilot survey, the following OLS regressions are estimated:

(1) $\mathrm{y}_{\mathrm{ij}}=\beta_{1}+\beta_{2}($ Car $)+\beta_{3}$ (Apartment $)+\beta_{4}($ Pension $)+\gamma($ Pension $) \mathrm{D}+\mu_{\mathrm{i}}+\varepsilon_{\mathrm{ij}}$ 
Where $\mathrm{y}_{\mathrm{ij}}$ represents an indicator of actual behavior such as the average score of the degree of search for information or the number of options considered by policymaker $i$ in decision $\mathrm{j}$, and $\mathrm{j}$ could be the apartment, car, large appliance or pension.

Car, Apartment and Pension are dummy variables that take the value of one if the reported answer is related to a car, an apartment or a pension fund, and zero otherwise (this vector of dummy variables is in fact decision fixed-effects). D is also a dummy variable that equals one if a policymaker i works in the Pension division (specialized policymakers), and zero otherwise (general policymaker). Finally, $\mu_{\mathrm{i}}$ captures individual fixed-effects to account for differences across individuals. For example, individuals who tend to search for more information before purchasing a car may also search more before buying an apartment.

The data for the estimation of Equation (1) are pooled observations across individuals' behavior (e.g. search for information) for all four decisions. Thus, a participant in the main survey could appear up to four times in the data. Excluding the last two terms in Equation (1), the estimated coefficients represent averages across individuals of each action. For example, in a regression of the number of options, the constant $\left(\beta_{1}\right)$ is just the average number of options considered before purchasing a large appliance and $\left(\beta_{1}+\beta_{4}\right)$ is the average number of options examined before choosing a pension fund.

\section{Criterion 1: Investment and importance}

Assuming a rational model, the degree of importance attach to a decision should affect the resources invested in that decision. The finding of the pilot survey may serve to formulate hypotheses regarding the extent of importance of each of the four decisions. Three features of investment in the decision process are examined in the main study to learn whether participants deviate from rational behavior: searching for more information regarding the considered options, considering more options, and spending more time on the decision process.

a) The extent of the search for information: $\beta_{4}=\beta_{3}>0$ and $\beta_{2}=0$

We have shown earlier that the participants in the pilot study rank pension and apartment decisions at the same degree of importance and higher than that of a car or a large appliance where the two later decisions are equally important. Therefore, we 
should expect that the coefficient of Pension (and Apartment) is significantly higher than zero to the extent that individuals are expected to devote more resources to more important decisions. It means that the expected average score of the search for information before choosing a pension fund $\left(\beta_{4}\right)$ and an apartment $\left(\beta_{3}\right)$ would be higher than that of a large appliance which is represented by the constant $\left(\beta_{1}\right)$. In addition, the coefficient of Car $\left(\beta_{2}\right)$ should be zero which means that the extent of the search for information before purchasing a car should be the same as for an appliance.

\section{b) Number of options considered: $\beta_{3}>\beta_{4}>0$ and $\beta_{2}=0$}

Participants in the pilot study were asked directly on what should be the desired number of options in all four decisions which allows us to specify the condition for a deviation. Participants in the pilot study recommend that before purchasing an apartment one should consider significantly higher number of options than before choosing a pension fund and that should be higher than before deciding on buying a new car or a large appliance. A different ordering would be considered a deviation.

c) Time allocated to decision: $\beta_{4}=\beta_{3}>0$ and $\beta_{2}=0$

Similarly to the extent of the search, the expected coefficient of Pension (and Apartment) in a regression of time allocated to decisions should be significantly higher than zero to the extent that individuals allocate more resources to more important decisions. Unlike the previous two features of investment, however, a certain task may be more time consuming than others and therefore spending more time on one task may not necessarily indicate on the degree of its importance. We will come back to this restriction when discussing the results.

\section{The three features of investment and the degree of expertise: $\gamma>0$}

We expect that specialized economic policymakers (as compared to general policymakers) would examine more options and search more for information because specific expertise reduces the cost of such activities and an ambiguous effect of expertise on the time allocated to the decision. Therefore, the coefficient on the interaction term between Pension and specialized policymakers in Equation (1) should be positive in the regressions for the extent of search and number of options and undecided for the time spent to the extent that the three chosen features represent important aspects of investment in the decision. This test may also be seen as another 
justification for using Criterion 1. A positive relation between the level of investment and the degree of expertise would suggest that investing more resources in the decision process is essential even for specialized policymakers and rules out the possibility that low investment by general policymakers reflect that they have in advance the necessary knowledge regarding the pension decision.

\section{Criterion 2: Examining one option}

The share of participants examining one option is another criterion for judging whether policymakers deviate from rational behavior. That share is compared to that in the three other decisions. Also, we examine whether the share of general policymakers who consider one option is different from that of specialized policymakers.

\section{Criterion 3: Knowledge about the chosen option}

Minimally, participants are expected to know the most relevant information regarding the chosen option such as management fees and total rate of return in the case of pension decision. Here we use a simple comparison of means to explore whether the actions of policymakers deviate from the rational choice model. In addition, a comparison of the state of knowledge between general and specialized policymakers is made.

\section{Results and Discussion}

\subsection{Investment and importance}

We begin our results report on economic policy experts' deviation from rational behavior by examining the extent of the search for information before making the decision. Table 2 shows that the extent of the search for information on key parameters of pension funds is relatively low for all policy experts. While the range of possible answer is between 1 and 7 to the three questions regarding the extent of the search for information, the average overall score of policy experts' answers is 3.26 for all participants and 3.28 for the 38 participants who completed all 4 parts of the questionnaire (Table 2). ${ }^{13}$

\footnotetext{
${ }^{13}$ Means of the extent to which participants searched for the relevant information regarding the pension decision are all below the mid-point of the scale (ranging from 1-7): management fees $(M=3.74)$, financial rate of return $(M=3.63)$, and demographic rate of return $(M=2.43)$. Specifically, the mode of those three self report measures is 1 , such that between $26 \%-36 \%$ of the participants have hardly searched for the most relevant information for their pension decision.
} 
Comparing the extent to which participants searched for relevant information before making the decision about their pension plan and the other three decisions (mean score of the three key parameters in choosing a pension fund as compared with mean score of the three most relevant information parameters searched for in each of the three other decision tasks), reveals that participants' information search is lower for the pension decision than for the other decisions which is apparently different from the order of importance that emerges from the pilot study.

Table 3 presents the results of estimating Equation (1) which allow us to examine whether the mentioned differences are also significant. Table 3 shows that the extent to which participants searched for the relevant information regarding the car purchasing is not significantly different from that of a large appliance, which is consistent with the hypothesis that $\beta_{2}=0$. We also find that indeed the extent to which participants searched for the relevant information is significantly higher for the apartment decision than that for the decision on the appliance or a car, which again is in line with the hypothesis raised before that $\beta_{3}>0$.

In contrast, Table 3 shows that in the regression of information search, the coefficient of Pension is lower by 1.5 points than that for a large appliance or a car and it is highly significant. Thus, the hypothesis that the coefficient of pension $\left(\beta_{4}\right)$ should be positive and equal to $\beta_{3}$ is rejected. In fact, the coefficient is negative and significant, which implies that participants' search for information is the lowest for the pension decision.

The low intensity of search for information in the case of pension is after controlling for individual fixed effects. In Table 3 we also account for the possibility that the search for information might be personality specific by including individual-fixed-effects. Those who tend to search for more information in the case of pension decision might also search more before they decide to buy an apartment, a car or a large appliance. Indeed, the extent of the search for information on pension fund is positively correlated with the extent of the search in all other three decision contexts.

A simple cost-benefit analysis suggests that individuals should search in accordance with the importance of the decision. However, we found that the extent to which participants search for relevant information on pension fund is not in line with the relative importance of pension decisions as compared with the other decisions suggested by the policy experts in the pilot study. 
One might speculate that experts should search less for information assuming that they already have that information. We have two indications that this is not the case. First, the degree of satisfaction from the decision is positively correlated with the extent of the search for information $\mathrm{r}=.433, \mathrm{p}<.001$, (See discussion below).

Second, the extent of the search is negatively correlated $(\mathrm{r}=-.332, \mathrm{p}<.001)$ with participants' agreement with the following statement "I would have been happier if I had more information at the time of the decision". Those who feel lack the information indeed searched less for information. Not having the relevant information regarding the chosen option at the time of the decision deviates from rational models, given that the participants in our study are experts who apparently know how to gain access to that information.

Table 3 demonstrates that specialized policymakers searched for significantly more information on key parameters of the pension decision than general policymakers, after controlling for individual and decision fixed effects. The extent of the search of these specialized policymakers is greater by 1.34 points which is relatively high given the scale range. This finding is also an indication that searching less for information could not be the result of prior knowledge that experts may hold.

Empirical research on experts' judgment and decision making shows that in many cases, surprisingly, experts do not exploit all the available information and search for less information than lay people (See Camerer and Johnson, 1997 and Shanteau 1992 for reviews). In contrast, our results show that specific experts search for more information than general experts. This is an important finding that may indicate the importance of the level of expertise in expert's judgment and decision making research.

The number of options considered is the second aspect of investment in the decision that is examined. Table 3 (third and fourth columns) shows that the coefficient of Pension is negative in a regression of the number of options considered, which is inconsistent with hypothesis that $\beta_{4}$ should be positive. The reported number of alternatives considered is the smallest for pension funds as compared with the other three decisions. This is in contrast with the number of alternatives recommended by the experts in the pilot study, which was on average 5 (ranking second after an apartment 
decision). Participants in the pilot study answered according to their belief of how ordinary people should act, but apparently they behave otherwise.

Specialized policymakers are evidently different from general policymakers also in the number of options considered. Specialized experts examine significantly more options before selecting the preferred pension fund. In contrast, both specialized experts and general experts consider the same number of options in all other three areas of decisions examined here (Table 2). Nevertheless, even specialized economic policy experts consider fewer options $(\mathrm{M}=3.3)$ than the recommended number suggested by experts from the same group of participants.

The third dimension of investment in the decision which we examined is the time dedicated to the decision process. An individual is expected to devote more time in the decision to invest $\$ 1,000,000$ than $\$ 10,000$. However, different tasks such as buying a car or choosing a pension fund may require different input of time and as a result the time devoted to a decision may not necessarily reflect the degree of importance. Subject to the above limitation, Table 3 reveals that while the participants have devoted more time to the decision of purchasing an apartment which is in line with the hypothesis outlined above $\left(\beta_{3}>0\right)$, the reported time spent to choose a pension fund is not significantly different from that of an appliance which is inconsistent with the rank of importance suggested by the participants in the pilot study (i.e., $\beta_{4}>0$ ). This finding is similar to Benartzi and Thaler, 1999 who report that 58 percent of faculty and staff at the University of Southern California spent less than one hour determining their contribution rate and investment elections.

Unlike the other decision aspects examined, there is no significant difference between specialized and general economic policy experts in terms of time devoted to the pension fund decision (Table 3). As mentioned before, the effect of expertise on the time devoted to the decision is theoretically ambiguous.

\subsection{Examining one option}

The tendency to consider only one option is much stronger in the pension decision than in any of the other three decisions examined. Among those who completed all four sections in the main study, the share of participants examining only one option before 
making the pension decision is significantly higher than the share of participants examining one option before making any of the other three decisions $\left(\chi^{2}(3)=95.78\right.$, $\mathrm{p}<.001$ ). A negligible share of the economic policymakers reported that they considered only one option before deciding on buying an apartment and a large appliance. The share of participants reported examining only one option before the decision about buying a car is also significantly lower than the share of participants who examined one option before deciding on a pension plan $\left(\chi^{2}(1)=19.55, \mathrm{p}<.001\right)$.

A striking finding emerges from the Table 4. A large share of economic policy experts (37\%) reported that they have considered only one option when they chose their preferred pension fund. Considering one option clearly does not fit with rational decision making, as no comparative perspective is available. Seemingly, this might reflect the power of institutional suggestion (a default choice). However, there is no explicit default in our context. As mentioned before, an employee who joins the Israeli Finance Ministry is given a form with a list of more than a dozen pension funds to choose from. The labor union as well is not involved in the process.

Yet, there might be an implicit default pension fund given the availability of suggested in-house experts (i.e., the professional staff at the Pension Division) with whom the participants could consult. However, the positive correlation between the number of options examined and extent to which participants consult colleagues $(r=0.25, \mathrm{p}<0.05)$ is inconsistent with that suggestion.

It could be that the workers have had prior knowledge on the pension plans that appear on the list and therefore tend to pick the one that is best for them without further research. For example, perhaps young workers knew they should choose the most aggressive plan, or old workers who knew they should invest in a pension fund with the lowest risk. But, we find a positive and significant correlation between the number of options examined and the state of knowledge. Participants who considered one option tend to report that they possess little information, or no knowledge about their chosen pension fund. Moreover, participants who examine fewer options are more likely to report that they would have been happier had they have more information at the time of the decision. 
Decision making literature has shown that examining one option without a comparable view may lead to biased decisions. Research on preference reversals between separate and joint evaluation reveals that evaluation of a single option tends to be dominated by spontaneous affective reactions (Ritov \& Kahneman, 1997; Slovic, Finucane, Peters, \& MacGregor, 2002) and by easily evaluated features (Hsee, 1996; Nowlis \& Simonson, 1997). Since options' attributes in the context of pension decisions can only be evaluated in a comparative view, examining one option isolated from a comparative context may enhance spontaneous and biased decisions that may not serve the decision maker's best interest.

The share of specialized policymakers who consider one pension fund is significantly lower than that of general policymakers $\left(\chi^{2}=8.09, \mathrm{p}<0.01\right)$. In contrast, the difference between the share of specialized and general economic policy experts who examine one option in all other three decisions is not significant (Table 4). These findings provide further evidence against the suggestion that considering one option is due to prior knowledge as specialized experts are expected to be more knowledgeable.

\subsection{Knowledge about the chosen option}

The last variable we examine, that may indicate a deviation from rational models of decision making, is the extent to which the decision maker had the most relevant information about the chosen pension plan. The results presented in Table 5 may be the most direct evidence to show some of the economic policymakers' departure from rational behavior. Policy experts not only search less, but also know less before they decide to select their preferred pension fund. These experts were asked to rank their chosen pension funds according to three key parameters: managerial fees, long-run financial rate of return and demographic rate of return. Almost 40 percent of these economic policy experts reported that they did not know the most basic information about the cost (managerial fees) and benefits (financial) of their selected pension fund. The results are similar also using demographic rate of return (not reported in the table).

This is a surprising result given that those policy experts allocate public resources to provide the general public with better information exactly on those three key parameters. In recent years a friendly web site with comparable managerial fees and financial rate of return across all pension funds was launched and widely publicized by the Israeli Finance Ministry. In addition, that same professional staff issued a directive 
that required all pension funds to send employees readable statements every three months. In particular, pension funds were ordered to make the managerial fees and other key factors more transparent.

However, specialized economic policy experts' behavior was significantly more in line with rational models than general experts (Table 5). The difference between the share of specialized and general economic policy experts who reported that they do not know what were the key parameters of their chosen pension fund is highly significant $\left(\chi^{2}=9.36, \mathrm{p}<0.01\right)$. Yet, even within the specialized experts there is almost 20 percent who have chosen their pension fund without knowing the most basic information.

The distribution of answers in Table 5 clearly shows that policy experts also tend to report better than average rate of return and lower than average managerial fees. This finding is consistent with earlier studies that documented overconfidence among experts (e.g., Lichtenstein Fischhoff and Phillips, 1982).

\subsection{Robustness test}

As robustness check for our results we examine whether individuals who search less for information, had very little knowledge about the chosen pension fund, examine low number of options (or even one) and spent little time on a decision are equally satisfied with the decision as other participants who search more, had the most relevant knowledge, considered more alternative and invested more time. In Table 6 we run the same type of regression appeared in Equation (1) but the dependent variable is the degree of satisfaction with the decision. As before, the right hand side includes a constant and three dummies for the four decisions and individual-fixed-effects to account for the fact that people who report a high degree of satisfaction in one area might demonstrate also high degree of satisfaction in other areas of life. The interaction term in this specification is the product of a Pension dummy and each of the three criteria according to which we examine the rationally of the decision.

As can be seen in Table 6, the first signal that something is special with regard to pension is the negative coefficient of Pension, which means that economic policymakers are significantly less satisfied with their Pension decision than in any of the other three decisions examined here. This result is significant after controlling for 
individual and decision fixed effects. In addition, the degree of satisfaction with the pension decision is positively associated with the extent of the search for information on pension decision. Policymakers who tend to search for more information before choosing a pension fund reported higher degree of satisfaction.

Table 6 further shows that participants who examined fewer options are more likely to be unsatisfied from their decision. The degree of satisfaction from the decision to select a particular pension fund is positively related to the number of options examined. ${ }^{14}$ This finding provides additional support to the interpretation that considering one option only is an indication for a deviation from rational choice model.

Those policymakers who reported that they had spent more time on the pension decision tend to show higher degree of satisfaction. While the negative coefficient on Pension may be alternatively interpreted as if pension decision is less time consuming, the positive coefficient on the interaction term implies that a participant who spent less time on pension decision is less satisfied, after controlling for the variable time needed for various decisions.

Table 6 also shows that the extent to which the decision makers had the most relevant information about the chosen pension plan significantly predicts the degree of satisfaction from the choice of the particular pension fund. Those who reported higher relative ranking (measured by costs/benefits indicators) of their chosen pension fund tend to exhibit higher degree of satisfaction.

\section{Conclusion}

This paper studies whether economic policymakers conform to the most basic principles of rational choice theory in their personal saving decisions. It is shown that economic policy experts deviate in their personal saving decisions from the rational choice theory (and even the bounded rationality theory). Economic policymakers at the Israeli Finance Ministry have hardly searched for the most relevant information for their pension decision. The extent to which participants searched for relevant information before choosing the preferred pension fund is the lowest among the four types of decisions examined in the current research and even less than before buying an

\footnotetext{
${ }^{14}$ A positive relation between the degree of satisfaction and the number of alternative options considered (up to a certain number) has been found also by Iyengar and Leeper (2000).
} 
appliance. It is shown that the extent to which participants searched for relevant information on a pension fund is not in line with the relative importance attributed to the pension decision in the pilot study in which policymakers were asked for their objective opinion without being judged about their own behavior.

Policymakers not only search less but also know less before they choose their pension fund. The surprising result is that almost 40 percent of these economic policymakers reported that they did not know the most basic information about the cost (managerial fees) and benefits (financial and demographic rates of return) of their chosen pension fund.

Another deviation from rational behavior is represented by the large share of economic policymakers (37\%) who reported that they have considered one option only when they chose their preferred pension fund. It is important to note that considering one option in the case of pension is not an institutional suggestion of a default choice. Moreover, the reported average number of alternative pension funds considered is the smallest among all four decision contexts which is inconsistent with the stated number of options recommended by policymakers in the pilot study. The actual time devoted to choose a pension fund is also not in line with what economic policymakers from the same group of participants suggested in the pilot survey.

A consistent pattern is found when participants are divided into two groups: specialized and general policymakers. Specialized policymakers search more for relevant information, know more about the costs/benefits indicators and consider more alternative options before choosing the preferred pension fund. Our results show that general policymakers are significantly more biased than Specialized policymakers (those who were asked about their particular domain, i.e. pension) and it seems that highly specific expertise is needed for unbiased decision making.

A recent paper (Kogut \& Dahan, 2008) suggests that the nature of pension decision may account for the deviations of policy experts from what is expected by rational choice models. The pension decision tends to raise unpleasant thoughts such as death, aging and health problems that people prefer to avoid. The way people get around those unpleasant feelings, is by giving minimum attention to the decision context. Another suggestion is that the pension decision is so complex that only specialized experts are 
not deterred to think about it which is in line with our findings on general and specialized policymakers.

The findings of this paper clearly suggest that policymakers should rethink the way they design policies regarding savings for retirement. Apparently, the pension decision is so complex that even well trained economic policy experts seem not to follow the principles of rational models held by most economic policy experts. The results of this research should stress the fact that in certain domains even trained economists who are familiar with decision models behave differently from what the blackboard description of rational choice theory suggests. 
Table 1: The degree of importance and the recommended number of options that should be considered by type of decision

Based on a pilot questionnaire (22 observations)

\begin{tabular}{|l|l|l|}
\hline Type of decision & Degree of importance & Number of options \\
\hline An apartment & 6.36 & 6.0 \\
\hline A pension fund & 5.41 & 5.0 \\
\hline A car & 3.64 & 4.2 \\
\hline A large appliance & 2.55 & 3.4 \\
\hline
\end{tabular}


Table 2: descriptive statistics

\begin{tabular}{|c|c|c|c|c|c|c|}
\hline decision & $\begin{array}{c}\text { Section } \\
\text { completed* }\end{array}$ & $\begin{array}{l}\text { Type of } \\
\text { policy } \\
\text { maker }\end{array}$ & $\begin{array}{l}\text { Extent of } \\
\text { the search } \\
\text { for } \\
\text { informatio } \\
\text { n mean } \\
\text { score } \\
\text { and s.d. }\end{array}$ & $\begin{array}{c}\text { No. of } \\
\text { options } \\
\text { considered } \\
\text { mean score } \\
\text { and s.d. }\end{array}$ & $\begin{array}{c}\text { Time } \\
\text { devoted to } \\
\text { decision } \\
\text { mean score } \\
\text { and s.d. }\end{array}$ & $\begin{array}{c}\text { No. of } \\
\text { observatio } \\
\text { ns }\end{array}$ \\
\hline \multirow[t]{7}{*}{ Pension } & Pension & All & $3.26(1.80)$ & 2.47 (1.63) & $2.49(1.38)$ & 136 \\
\hline & Pension & general & $2.91(1.64)$ & $2.15(1.32)$ & $2.51(1.45)$ & 98 \\
\hline & Pension & Specialized & $4.16(1.90)$ & $3.29(2.03)$ & $2.42(1.20)$ & 38 \\
\hline & $\begin{array}{l}\text { Pension \& } \\
\text { apartment }\end{array}$ & All & 3.17 (1.77) & $2.24(1.33)$ & $2.44(1.37)$ & 61 \\
\hline & $\begin{array}{l}\text { Pension \& } \\
\text { car }\end{array}$ & All & $3.17(1.70)$ & $2.34(1.47)$ & $2.48(1.42)$ & 104 \\
\hline & $\begin{array}{l}\text { Pension \& } \\
\text { appliance }\end{array}$ & All & $3.48(1.81)$ & $2.68(1.74)$ & 2.59 (1.38) & 96 \\
\hline & $\begin{array}{l}\text { All four } \\
\text { sections }\end{array}$ & All & $3.28(1.74)$ & $2.16(1.15)$ & 2.50 (1.35) & 38 \\
\hline \multirow[t]{4}{*}{ Apartment } & $\begin{array}{l}\text { Apartment } \\
\text { \& Pension }\end{array}$ & All & $5.91(1.25)$ & 5.85 (1.77) & 4.23 (1.24) & 61 \\
\hline & $\begin{array}{l}\text { Apartment } \\
\text { \& Pension }\end{array}$ & general & $6.14(0.89)$ & $5.91(1.76)$ & $4.24(1.30)$ & 45 \\
\hline & $\begin{array}{l}\text { Apartment } \\
\text { \& Pension }\end{array}$ & Specialized & $5.25(1.82)$ & $5.69(1.85)$ & $4.19(1.11)$ & 16 \\
\hline & $\begin{array}{l}\text { All four } \\
\text { sections }\end{array}$ & All & $6.01(1.10)$ & $5.76(1.75)$ & $4.39(1.08)$ & 38 \\
\hline \multirow[t]{4}{*}{ Car } & $\begin{array}{l}\text { Car \& } \\
\text { Pension }\end{array}$ & All & $4.42(1.49)$ & $3.40(1.81)$ & $3.32(1.35)$ & 104 \\
\hline & $\begin{array}{l}\text { Car \& } \\
\text { Pension }\end{array}$ & general & $4.44(1.54)$ & $3.45(1.86)$ & $3.37(1.32)$ & 78 \\
\hline & $\begin{array}{l}\text { Car \& } \\
\text { Pension }\end{array}$ & Specialized & 4.35 (1.34) & $3.27(1.71)$ & $3.15(1.46)$ & 26 \\
\hline & $\begin{array}{l}\text { All four } \\
\text { sections }\end{array}$ & All & 4.39 (1.52) & $3.13(1.74)$ & $2.97(1.20)$ & 38 \\
\hline \multirow[t]{4}{*}{ Appliance } & $\begin{array}{l}\text { Appliance } \\
\text { \& Pension }\end{array}$ & All & $5.02(1.22)$ & $3.91(1.60)$ & 2.81 (1.19) & 96 \\
\hline & $\begin{array}{l}\text { Appliance } \\
\& \text { Pension }\end{array}$ & general & $5.01(1.20)$ & $3.90(1.59)$ & $2.75(1.21)$ & 67 \\
\hline & $\begin{array}{l}\text { Appliance } \\
\text { \& Pension }\end{array}$ & Specialized & $5.05(1.27)$ & $3.93(1.67)$ & $2.97(1.15)$ & 29 \\
\hline & $\begin{array}{l}\text { All four } \\
\text { sections }\end{array}$ & All & 4.96 (1.29) & $3.82(1.43)$ & 2.84 (1.39) & 38 \\
\hline
\end{tabular}

* Means and standard deviations are based on those policymakers who answered that particular section(s). Standard deviations are in parentheses. 
Table 3: OLS regressions for the extent of the search for relevant information, number of options considered and time devoted (with in individuals fixed-Effects)

\begin{tabular}{|c|c|c|c|c|c|c|}
\hline & \multicolumn{6}{|c|}{ The dependent variable } \\
\hline & \multicolumn{2}{|c|}{$\begin{array}{l}\text { Average score in } \\
\text { extent of the search } \\
\text { for information }\end{array}$} & \multicolumn{2}{|c|}{$\begin{array}{l}\text { Number of Options } \\
\text { considered }\end{array}$} & \multicolumn{2}{|c|}{$\begin{array}{c}\text { Average score on } \\
\text { time devoted to } \\
\text { decision }\end{array}$} \\
\hline & (1) & (2) & (3) & (4) & (5) & (6) \\
\hline $\begin{array}{l}\text { Constant } \\
\text { (Appliance) }\end{array}$ & $\begin{array}{r}\text { 4.82*** } \\
(35.00) \\
\end{array}$ & $\begin{array}{r}\mathbf{4 . 8 4} * * * \\
(36.34) \\
\end{array}$ & $\begin{array}{l}\text { 3.74*** } \\
(23.25) \\
\end{array}$ & $\begin{array}{l}\text { 3.76*** } \\
(23.82) \\
\end{array}$ & $\begin{array}{l}2.72 * * * \\
(23.39) \\
\end{array}$ & $\begin{array}{l}2.72 * * * \\
(23.33)\end{array}$ \\
\hline Car & $\begin{array}{c}-0.32 \\
(-1.63) \\
\end{array}$ & $\begin{array}{l}-0.35 * \\
(-1.89) \\
\end{array}$ & $\begin{array}{c}-0.30 \\
(-1.32) \\
\end{array}$ & $\begin{array}{c}-0.34 \\
(-1.52) \\
\end{array}$ & $\begin{array}{c}\mathbf{0 . 5 8} * * * \\
(3.57)\end{array}$ & $\begin{array}{c}\mathbf{0 . 5 9} * * * \\
(3.57)\end{array}$ \\
\hline Apartment & $\begin{array}{c}1.18 * * * \\
(5.15)\end{array}$ & $\begin{array}{c}1.17 * * * \\
(5.27)\end{array}$ & $\begin{array}{c}2.35 * * * \\
(8.74) \\
\end{array}$ & $\begin{array}{c}2.34 * * * \\
(8.88)\end{array}$ & $\begin{array}{c}1.64 * * * \\
(8.45)\end{array}$ & $\begin{array}{c}1.64 * * * \\
(8.44)\end{array}$ \\
\hline Pension & $\begin{array}{c}-1.52 * * * \\
(-8.48)\end{array}$ & $\begin{array}{c}-1.92 * * * \\
(-9.81)\end{array}$ & $\begin{array}{c}-1.30 * * * \\
(-6.14)\end{array}$ & $\begin{array}{c}-1.66 * * * \\
(-7.11)\end{array}$ & $\begin{array}{c}-0.22 \\
(-1.46)\end{array}$ & $\begin{array}{l}-0.20 \\
(-1.14)\end{array}$ \\
\hline $\begin{array}{l}\text { Specialized } \\
\text { experts* } \\
\text { pension } \\
\end{array}$ & & $\begin{array}{c}1.34 * * * \\
(4.39)\end{array}$ & & $\begin{array}{c}1.22 * * * \\
(3.38)\end{array}$ & & $\begin{array}{c}-0.09 \\
(-0.34)\end{array}$ \\
\hline $\mathbf{R}^{2}$ within & 0.413 & 0.454 & 0.450 & 0.473 & 0.315 & 0.315 \\
\hline $\mathbf{R}^{2}$ between & 0.146 & 0.179 & 0.095 & 0.126 & 0.032 & 0.032 \\
\hline $\mathbf{R}^{2}$ overall & 0.276 & 0.311 & 0.303 & 0.325 & 0.172 & 0.172 \\
\hline $\begin{array}{l}\text { Num of } \\
\text { observations }\end{array}$ & 397 & 397 & 395 & 395 & 397 & 397 \\
\hline
\end{tabular}

***Significance at $1 \%$; ** Significance at $5 \%$; *significance at $10 \%$ 
Table 4: The share of participants who considered one option only by decision

\begin{tabular}{|l|c|c|c|c|}
\hline & Pension & Apartment & Car & Appliance \\
\hline All $^{1}$ & $37 \%$ & $5 \%$ & $20 \%$ & $3 \%$ \\
\hline general & $45 \%$ & $4 \%$ & $19 \%$ & $3 \%$ \\
\hline Specialized & $18 \%$ & $6 \%$ & $23 \%$ & $3 \%$ \\
\hline $\begin{array}{l}\text { The significance } \\
\text { of the difference }\end{array}$ & $\chi^{2}=8.094$, & $\chi^{2}=.179, \mathrm{NS}$ & $\chi^{2}=.082, \mathrm{NS}$ & $\chi^{2}=.014, \mathrm{NS}$ \\
\hline Observations & $\mathbf{1 3 6}$ & & & \\
\hline
\end{tabular}

1. For the 38 participants who completed all four sections in the main study, the share of participants examining only one pension fund is significantly higher than any of the other three decisions $\left(\chi^{2}(3)=95.78, \mathrm{p}<.001\right)$. The difference is significant also when comparing between a pension fund and a car $\left(\chi^{2}(1)=19.55\right.$, $\mathrm{p}<.001)$.

2. A test for the difference between general and specialized policymakers. 
Table 5: Experts' information about their chosen pension fund at the time of the decision- a distribution of answers

\begin{tabular}{|c|c|c|c|c|c|c|c|c|}
\hline \multicolumn{5}{|c|}{ Management fees } & \multicolumn{4}{|c|}{ Long-run financial rate of return } \\
\hline Answer & $\begin{array}{c}\text { All } \\
\text { experts }\end{array}$ & $\begin{array}{l}\text { General } \\
\text { experts }\end{array}$ & $\begin{array}{l}\text { Spec. } \\
\text { experts }\end{array}$ & & All experts & $\begin{array}{l}\text { General } \\
\text { experts }\end{array}$ & $\begin{array}{c}\text { Spec. } \\
\text { experts }\end{array}$ & \\
\hline $\begin{array}{l}\text { 0- I don't } \\
\text { know }\end{array}$ & $39 \%$ & $47 \%$ & $18 \%$ & $\begin{array}{l}\chi^{2}=9.363, \\
p<.01\end{array}$ & $42 \%$ & $51 \%$ & $21 \%$ & $\begin{array}{l}\chi^{2}=9.716, \\
p<.01\end{array}$ \\
\hline $\begin{array}{l}\text { 1-much less } \\
\text { than } \\
\text { average }\end{array}$ & $26 \%$ & $16 \%$ & $3 \%$ & & $1 \%$ & $1 \%$ & $0 \%$ & \\
\hline $\begin{array}{l}\text { 2-little less } \\
\text { than } \\
\text { average }\end{array}$ & $10 \%$ & $10 \%$ & $3 \%$ & & $1 \%$ & $1 \%$ & $0 \%$ & \\
\hline $\begin{array}{l}\text { 3-about } \\
\text { average }\end{array}$ & $17 \%$ & $17 \%$ & $16 \%$ & & $21 \%$ & $19 \%$ & $26 \%$ & \\
\hline $\begin{array}{l}\text { 4-little more } \\
\text { than } \\
\text { average }\end{array}$ & $4 \%$ & $5 \%$ & $11 \%$ & & $24 \%$ & $19 \%$ & $37 \%$ & \\
\hline $\begin{array}{l}\text { 5- much } \\
\text { more than } \\
\text { average }\end{array}$ & $4 \%$ & $4 \%$ & $50 \%$ & & $12 \%$ & $10 \%$ & $16 \%$ & \\
\hline Average & 2.33 & 1.89 & 3.47 & $\begin{array}{l}t(134)=4.18 \\
, p<.001\end{array}$ & 2.19 & 1.85 & 3.05 & $\begin{array}{l}t(133)=3.30, \\
p<.001\end{array}$ \\
\hline $\begin{array}{l}\text { Standard } \\
\text { deviation }\end{array}$ & 2.10 & 2.00 & 1.94 & & 1.98 & 1.98 & 1.72 & \\
\hline $\begin{array}{l}\text { No. of } \\
\text { observations }\end{array}$ & 136 & 98 & 38 & & 135 & 97 & 38 & \\
\hline
\end{tabular}


Table 6: Satisfaction and the extent of the search for information, knowledge, number of options considered and time devoted (with individual-fixed-Effects)

The dependent variable: the degree of satisfaction

\begin{tabular}{|c|c|c|c|c|c|c|}
\hline & (1) & (2) & (3) & (4) & (5) & (6) \\
\hline Constant (Appliance) & $\begin{array}{l}\mathbf{5 . 4 7 * * *} \\
(36.18)\end{array}$ & $\begin{array}{l}\mathbf{5 . 5 1} * * * \\
(37.95)\end{array}$ & $\begin{array}{l}\mathbf{5 . 4 9 * * *} \\
(36.41)\end{array}$ & $\begin{array}{l}5.49 * * * \\
(37.16)\end{array}$ & $\begin{array}{l}\mathbf{5 . 4 8 * * *} \\
(37.51)\end{array}$ & $\begin{array}{r}\mathbf{5 . 4 9 * * *} \\
(36.70)\end{array}$ \\
\hline Car & $\begin{array}{c}0.13 \\
(0.60)\end{array}$ & $\begin{array}{c}0.06 \\
(0.28)\end{array}$ & $\begin{array}{c}0.10 \\
(0.46)\end{array}$ & $\begin{array}{c}0.10 \\
(0.50)\end{array}$ & $\begin{array}{c}0.11 \\
(0.54)\end{array}$ & $\begin{array}{c}0.10 \\
(0.45)\end{array}$ \\
\hline Apartment & $\begin{array}{c}\mathbf{0 . 7 8} * * * \\
(3.11)\end{array}$ & $\begin{array}{c}\text { 0.73*** } \\
(3.00)\end{array}$ & $\begin{array}{c}\text { 0.74*** } \\
(2.92)\end{array}$ & $\begin{array}{c}\text { 0.75*** } \\
(3.05)\end{array}$ & $\begin{array}{c}\mathbf{0 . 7 7 * * *} \\
(3.14)\end{array}$ & $\begin{array}{c}\mathbf{0 . 7 4} * * * \\
(2.96)\end{array}$ \\
\hline Pension & $\begin{array}{c}-\mathbf{- 1 . 2 9 * * *} \\
(-6.53)\end{array}$ & $\begin{array}{c}-2.68 * * * \\
(-7.78)\end{array}$ & $\begin{array}{c}\mathbf{- 1 . 8 4 * * *} \\
(-5.74)\end{array}$ & $\begin{array}{c}-2.32 * * * \\
(-6.83)\end{array}$ & $\begin{array}{c}-2.22 * * * \\
(7.73)\end{array}$ & $\begin{array}{c}\mathbf{- 1 . 8 9 * * *} \\
(-6.52)\end{array}$ \\
\hline $\begin{array}{l}\text { Extent of search * } \\
\text { Pension } 1\end{array}$ & & $\begin{array}{c}\mathbf{0 . 4 1} * * * \\
(4.83)\end{array}$ & & & & \\
\hline $\begin{array}{l}\text { Number of options * } \\
\text { Pension }\end{array}$ & & & $\begin{array}{l}\mathbf{0 . 2 2 * *} \\
(2.27)\end{array}$ & & & \\
\hline Time spent $*$ Pension & & & & $\begin{array}{c}\mathbf{0 . 4 0} * * * \\
(3.67)\end{array}$ & & \\
\hline Knowledge* Pension $^{2}$ & & & & & $\begin{array}{c}1.38 * * * \\
(4.34)\end{array}$ & \\
\hline $\begin{array}{l}\text { Considered more than } \\
\text { one option } * \text { Pension }^{3}\end{array}$ & & & & & & $\begin{array}{c}\mathbf{0 . 9 4 * * *} \\
(2.93)\end{array}$ \\
\hline $\mathbf{R}^{2}$ within & 0.290 & 0.349 & 0.296 & 0.326 & 0.339 & 0.305 \\
\hline $\mathbf{R}^{2}$ between & 0.119 & 0.149 & 0.211 & 0.167 & 0.136 & 0.192 \\
\hline $\mathbf{R}^{2}$ overall & 0.209 & 0.273 & 0.236 & 0.247 & 0.254 & 0.246 \\
\hline Num of observations & 397 & 397 & 395 & 397 & 397 & 395 \\
\hline
\end{tabular}

***Significance at 1\%; ** Significance at 5\%; *significance at $10 \%$

1 . The average score of the extent of the search for managerial fees, long-run financial rate of return and demographic rate of return.

2. Knowledge is a dummy variable that take the value of one if policy experts know the managerial fees or long-run financial rate of return in their chosen pension fund and zero otherwise.

3. A dummy variable that take the value of one if policymakers considered more than one option and zero otherwise. 


\section{References}

Alba, Joseph W. and Hutchinson, J. Wesley. (1987). "Dimensions of expertise." Journal of Consumer Research, 13 (March), 411-454.

Baron Jonathan, (2000) Thinking and Deciding, Third Edition, Cambridge University Press. Bazerman, Max H.. (1998). Judgment in Managerial Decision Making. (4 ${ }^{\text {rd }}$ ed) New York: Wiley.

Ben Bassat Avi and Dahan Momi, The Balance of Power in the Budgeting Process, Published by The Israel Democracy Institute, 2006 (Hebrew)

Ben-Bassat, Avi, (2008), "Conflicts, Interest Groups, and Politics in Structural Reform" Available at SSRN: http://ssrn.com/abstract $=1210584$

Benartzi, Shlomo and Richard, Thaler. (1999). "Risk Aversion or Myopia? Choices in Repeated Gambles and Retirement Investments." Management science 45.3:364381.

Benartzi, Shlomo, and Richard H. Thaler, (2007), "Heuristics and Biases in Retirement Savings Behavior." Journal of Economic Perspectives, 21(3), 81-104.

Bettman, James R.. and Sujan, Mita. (1987). "Effects of framing on evaluation of comparable and noncomparable alternatives by expert and novice consumers" Journal of Consumer Research, 14, 141-154.

Camerer Colin and Johnson Eric, (1991), "The process-performance paradox in expert judgment: How can experts know so much and predict so badly?", In: K.A. Ericsson and J. Smith, Editors, Towards a General Theory of Expertise, Cambridge University Press, pp. 195-217.

Camerer Colin and Johnson Eric, (1997), "The process-performance paradox in expert judgment: How can experts know so much and predict so badly? Edited by William M. Goldstein and Robin M. Hogarth , Research on Judgment and Decision Making, 342-364, Cambridge Series on Judgment and Decision Making.

Choi, James J., David Laibson, Brigitte Madrian, and Andrew Metrick (2002), "Defined Contribution Pensions: Plan Rules, Participant Decision, and the Path of Least Resistance.", Tax Policy and the Economy, 16, ed. Poterba, 67-113, MIT Press.

Choi, James J., David Laibson, Brigitte Madrian, and Andrew Metrick (2004), "For Better or For Worse: Default Effects and 401(k) Savings Behavior” in David Wise 
editor, Perspectives in the Economics of Aging. Chicago, IL: University of Chicago Press, 81-121.

Coupey, Eloise., Irwin, Julie R., and Payne, John W.(1998). "Product category

familiarity and preference construction", Journal of Consumer Research. 24(4), 459-468.

Davidow, Joseph and Levinson, Edward M. (1993), "Heuristic principles and cognitive bias in decision making Implications for assessment in school Psychology in the Schools, 30, 351-361.

Das T.K. and Teng, Bing-Sheng (1999), "Cognitive biases and strategic decision processes". Journal of Management Studies, 36, 757-778.

Hall, Katherine H. (2002). "Reviewing intuitive decision-making and uncertainty: The implications for medical education", Medical Education, 36, 216-224

Hsee, Christopher. (1996). "The evaluability hypothesis: An explanation for preference reversals between joint and separate evaluations of alternatives", Organizational Behavior and Human Decision Processes, 67(3), 247-257.

Hodgkinson, Gerard .P., Bown, Nicola, Maule, A. John, Glaister, Keith W., and

Pearman, Alan D. (1999). "Breaking the frame: An analysis of strategic cognition and decision-making under uncertainty", Strategic Management Journal, 20, 977985.

Kogut Tehila and Dahan Momi, (2008), "Do you look forward to retirement? Motivational biases in experts' pension decisions".

Lichtenstein Sarah, Fischhoff Baruch, \& Phillips Lawrence D.(1982). Calibration of probabilities: The state of the art to 1980. In Daniel Kahneman, Paul Slovic, \& Amos Tversky (Eds.), Judgment under uncertainty: Heuristics and biases. New York: Cambridge Univ. Press.

Madrian, Brigitte C. and Shea, Dennis F., "The Power of Suggestion: Inertia in 401(k) Participation and Savings Behavior." Quarterly Journal of Economics, 116(4), 1149-1525.

Mandel, Naomi and Johnson, Eric J.(2002). "When web pages influence choice: effects ofvisual primes on experts and novices", Journal of Consumer Research. 29, 235246.

Mitchell Olivia and Utkus Stephen (2004) "Lessons from behavioral finance for retirement plan design" in Pension Design and Structure: New Lessons from Behavioral Finance. Edited by Mitchell Olivia and Utkus Stephen, Oxford: Oxford University Press 
Nowlis, . Stephen. and Simonson, Itamar. (1997). "Attribute-task compatibility as a determinant of consumer preference reversals", Journal of Marketing Research, 34(2), 205-218.

Nothcraft Gregory B. and Neale Margaret A. (1987). "Expert, amateurs, and real estate: An anchoring-and-adjustment perspective on property pricing decisions." Organizational Behavior and Human Decision Processes, 39, 84-97.

Olsen, Robert A. (1997). "Desirability bias among professional investment managers: Some evidence from experts." Journal of Behavioral Decision Making, 10, 65-72 Phelps, Ruth H. and Shanteau, James (1978), "Livestock judges: how much information can an expert use?" Organizational Behavior \& Human Performance. Vol 21(2), Apr. 209-219.

Shanteau, James (1992) "Competence in experts: the role of task characteristics." Organizational Behavior and Human Decision Processes, 53 , 252-266.

Simon, HA. (1956). Rational choice and the structure of environments. Psychological Review,63, 129-138.

Slovic, P., Finucane, M., Peters, E., \& MacGregor, D. (2002, a), "The affect heuristic", In T. Gilovich, D. Griffin, \& D. Kahneman (Eds.), Heuristics and biases: The psychology of intuitive judgment. Cambridge University press.

Ritov, Ilana and Kahneman, Daniel (1997), "How people value the environment: Attitudes versus economic values", In Bazerman, M. H. and Messick, D. M. (Eds). Environment, ethics, and behavior: The psychology of environmental valuation and degradation. The New Lexington Press.

Tversky Amos and Kahneman Daniel. (1971). The belief in the "low of small numbers". Psychological Bulletin, 76, 105-110.

Tversky Amos \& Kahneman Daniel. (1974). Judgment under uncertainty: heuristics and biases, Science , 185, 1124-1131.

Tversky Amos \& Kahneman Daniel. (1973). "Availability: A heuristic for judging frequency and probability.", Cognitive Psychology, 4, 207-232.

Tversky Amos \& Kahneman Daniel. (1991). "Judgment and Decision Making: A Personal View.", Psychological Science, 2(3), May, 142-145.

Wright, Peter and Rip Peter D.(1980), Product class advertising effects on first time buyers’ decision strategies. Journal of Consumer Research, 7, 176-188. 


\section{CESifo Working Paper Series}

for full list see www.cesifo-group.org/wp

(address: Poschingerstr. 5, 81679 Munich, Germany, office@cesifo.de)

2721 Thushyanthan Baskaran and Lars P. Feld, Fiscal Decentralization and Economic Growth in OECD Countries: Is there a Relationship?, July 2009

2722 Nadia Fiorino and Roberto Ricciuti, Interest Groups and Government Spending in Italy, 1876-1913, July 2009

2723 Andreas Wagener, Tax Competition, Relative Performance and Policy Imitation, July 2009

2724 Hans Fehr and Fabian Kindermann, Pension Funding and Individual Accounts in Economies with Life-cyclers and Myopes, July 2009

2725 Ernesto Reuben and Arno Riedl, Enforcement of Contribution Norms in Public Good Games with Heterogeneous Populations, July 2009

2726 Kurt Schmidheiny and Marius Brülhart, On the Equivalence of Location Choice Models: Conditional Logit, Nested Logit and Poisson, July 2009

2727 Bruno S. Frey, A Multiplicity of Approaches to Institutional Analysis. Applications to the Government and the Arts, July 2009

2728 Giovanni Villani, A Strategic R\&D Investment with Flexible Development Time in Real Option Game Analysis, July 2009

2729 Luca Di Corato and Michele Moretto, Investing in Biogas: Timing, Technological Choice and the Value of Flexibility from Inputs Mix, July 2009

2730 Gilad D. Aharonovitz, Nathan Skuza and Faysal Fahs, Can Integrity Replace Institutions? Theory and Evidence, July 2009

2731 Michele Moretto and Sergio Vergalli, Managing Migration through Conflicting Policies: an Option-theory Perspective, July 2009

2732 Volker Nitsch, Fly or Cry: Is Airport Noise Costly?, July 2009

2733 Francesco Cinnirella and Joachim Winter, Size Matters! Body Height and Labor Market Discrimination: A Cross-European Analysis, July 2009

2734 Samuel Bowles and Sandra Polanía Reyes, Economic Incentives and Social Preferences: A Preference-based Lucas Critique of Public Policy, July 2009

2735 Gary Burtless, Lessons of the Financial Crisis for the Design of National Pension Systems, July 2009 
2736 Helmuth Cremer, Firouz Gahvari and Pierre Pestieau, Fertility, Human Capital Accumulation, and the Pension System, July 2009

2737 Hans Jarle Kind and Frank Stähler, Market Shares in Two-Sided Media Industries, July 2009

2738 Pamela Campa, Alessandra Casarico and Paola Profeta, Gender Culture and Gender Gap in Employment, August 2009

2739 Sebastian Gechert, Supplementary Private Health Insurance in Selected Countries: Lessons for EU Governments?, August 2009

2740 Leif Danziger, Endogenous Monopsony and the Perverse Effect of the Minimum Wage in Small Firms, August 2009

2741 Yan Dong and John Whalley, A Third Benefit of Joint Non-OPEC Carbon Taxes: Transferring OPEC Monopoly Rent, August 2009

2742 Valentina Bosetti, Carlo Carraro and Massimo Tavoni, Climate Change Mitigation Strategies in Fast-Growing Countries: The Benefits of Early Action, August 2009

2743 Christina Felfe, The Willingness to Pay for Job Amenities: Evidence from Mothers' Return to Work, August 2009

2744 Jörg Franke, Christian Kanzow, Wolfgang Leininger and Alexandra Väth, Effort Maximization in Asymmetric N-Person Contest Games, August 2009

2745 Bruno S. Frey and Paolo Pamini, Making World Heritage Truly Global: The Culture Certificate Scheme, August 2009

2746 Frank N. Caliendo, Is Social Security behind the Collapse of Personal Saving?, August 2009

2747 Caterina Liesegang and Marco Runkel, Corporate Income Taxation of Multinationals and Fiscal Equalization, August 2009

2748 Chrysovalantou Milliou and Apostolis Pavlou, Upstream Horizontal Mergers and Efficiency Gains, August 2009

2749 Rüdiger Pethig and Christian Wittlich, Interaction of Carbon Reduction and Green Energy Promotion in a Small Fossil-Fuel Importing Economy, August 2009

2750 Kai Carstensen, Oliver Hülsewig and Timo Wollmershäuser, Monetary Policy Transmission and House Prices: European Cross-country Evidence, August 2009

2751 Olaf Posch, Explaining Output Volatility: The Case of Taxation, August 2009

2752 Beatrice Scheubel, Daniel Schunk and Joachim Winter, Don't Raise the Retirement Age! An Experiment on Opposition to Pension Reforms and East-West Differences in Germany, August 2009 
2753 Daniel G. Arce, Dan Kovenock and Brian Roberson, Suicide Terrorism and the Weakest Link, August 2009

2754 Mario Larch and Wolfgang Lechthaler, Comparative Advantage and Skill-Specific Unemployment, August 2009

2755 Horst Raff and Nicolas Schmitt, Buyer Power in International Markets, August 2009

2756 Seppo Kari, Hanna Karikallio and Jukka Pirttilä, The Impact of Dividend Taxation on Dividends and Investment: New Evidence Based on a Natural Experiment, August 2009

2757 Mirco Tonin and Michael Vlassopoulos, Disentangling the Sources of Pro-social Behavior in the Workplace: A Field Experiment, August 2009

2758 Nicole Grunewald and Inmaculada Martínez-Zarzoso, Driving Factors of Carbon Dioxide Emissions and the Impact from Kyoto Protocol, August 2009

2759 Yu-Fu Chen and Michael Funke, Booms, Recessions and Financial Turmoil: A Fresh Look at Investment Decisions under Cyclical Uncertainty, August 2009

2760 Jan-Egbert Sturm and Jakob de Haan, Does Central Bank Communication really Lead to better Forecasts of Policy Decisions? New Evidence Based on a Taylor Rule Model for the ECB, August 2009

2761 Larry Karp, Sacrifice, Discounting and Climate Policy: Five Questions, August 2009

2762 Marianna Belloc and Samuel Bowles, International Trade, Factor Mobility and the Persistence of Cultural-Institutional Diversity, August 2009

2763 Charles Noussair and Fangfang Tan, Voting on Punishment Systems within a Heterogeneous Group, August 2009

2764 Birgit Bednar-Friedl and Karl Farmer, Internationally Coordinated Emission Permit Policies: An Option for Withdrawers from the Kyoto Protocol?, August 2009

2765 Pierre M. Picard and David E. Wildasin, Labor Market Pooling, Outsourcing and Labor Contracts, August 2009

2766 Stefan Voigt and Lorenz Blume, The Economic Effects of Federalism and Decentralization - A Cross-Country Assessment, August 2009

2767 David S. Jacks, Christopher M. Meissner and Dennis Novy, Trade Booms, Trade Busts, and Trade Costs, August 2009

2768 Mario Jametti and Thomas von Ungern-Sternberg, Hurricane Insurance in Florida, August 2009

2769 Alessandro Balestrino, Kind of Black: The Musicians’ Labour Market in Italy, August 2009 
2770 Yosr Abid Fourati and Cathal O’Donoghue, Eliciting Individual Preferences for Pension Reform, August 2009

2771 Christian Breuer and Chang Woon Nam, VAT on Intra-Community Trade and Bilateral Micro Revenue Clearing in the EU, August 2009

2772 Choudhry Tanveer Shehzad, Jakob De Haan and Bert Scholtens, Growth and Earnings Persistence in Banking Firms: A Dynamic Panel Investigation, August 2009

2773 Erdal Yalcin, Uncertain Productivity Growth and the Choice between FDI and Export, August 2009

2774 Klaus Abberger, Wolfgang Nierhaus and Shynar Shaikh, Findings of the Signal Approach for Financial Monitoring in Kazakhstan, September 2009

2775 Sascha O. Becker, Francesco Cinnirella and Ludger Woessmann, The Trade-off between Fertility and Education: Evidence from before the Demographic Transition, September 2009

2776 Thomas Aronsson and Erkki Koskela, Optimal Income Taxation, Outsourcing and Policy Cooperation in a Dynamic Economy, September 2009

2777 Joel Slemrod, Old George Orwell Got it Backward: Some Thoughts on Behavioral Tax Economics, September 2009

2778 Cagri Seda Kumru and Athanasios C. Thanopoulos, Social Security Reform and Temptation, September 2009

2779 Alessandro Bucciol and Roel M. W. J. Beetsma, Inter- and Intra-generational Consequences of Pension Buffer Policy under Demographic, Financial and Economic Shocks, September 2009

2780 Eduardo Strube and Marcelo Resende, Complementarity of Innovation Policies in the Brazilian Industry: An Econometric Study, September 2009

2781 Henry Tulkens and Vincent van Steenberghe, "Mitigation, Adaptation, Suffering": In Search of the Right Mix in the Face of Climate Change, September 2009

2782 Maria L. Loureiro, Anna Sanz-de-Galdeano and Daniela Vuri, Smoking Habits: Like Father, Like Son, Like Mother, Like Daughter, September 2009

2783 Momi Dahan, Tehila Kogut and Moshe Shalem, Do Economic Policymakers Practice what they Preach? The Case of Pension Decisions, September 2009 